\title{
Participation Action Research dalam Membangun Kesadaran Pendidikan Anak di Lingkungan Perkampungan Transisi Kota
}

\author{
Ali Muhtarom \\ Universitas Islam Negeri Sultan Maulana Hasanudin Banten \\ Email: jeporomuhtarom@gmail.com
}

\begin{abstract}
This paper provides an overview of efforts to overcome the inequality of education of children in a village that is transitioning to urban society. Perkampungn close to the center of the crowd like terminals, shopping centers, tourist attractions and others. However, the reality of people in the region is not comparable to access to urban, industrial, and educational and government routes. The Tegal Jeruk Hamlet community has been left behind economically and also in education. Poverty is a source of problems from the underdevelopment of people in the region, so at the same time, it is found that many teenagers in this region experience uncertainty about the future due to difficult economic and educational affordability. Through the Particular Action Research (PAR) approach, this program is focused on building awareness of children's education in urban transition villages by conducting community service workshops and empowering youth through life skill education activities in the form of skills that they do not get in formal schools.
\end{abstract}

Abstrak: Tulisan ini memberikan gambaran upaya mengatasi ketimpangan pendidikan anak di lingkungan perkampungan yang tengah bertransisi menuju masyarakat kota. Perkampungn yang dekat dengan pusat keramaian laiknya terminal, pusat perbelanjaan, tempat wisata dan lain-lain. Akan tetapi, realitas masyarakat di wilayah tersebut tidak sebanding akses ke jalur kota, perindustrian, maupun pusat pendidikan dan pemerintahan. Masyarakat Dusun Tegal Jeruk mengalami ketertinggalan secara ekonomi dan juga pendidikan. Kemiskinan menjadi sumber persoalan dari ketertinggalan masyarakat di wilayah tersebut, sehingga pada saat yang sama, banyak ditemukan kalangan masyarakat remaja di wilayah ini mengalami ketidakpastian masa depan karena ketidakterjangkauan pendidikan dan ekonomi yang sulit. Melalui pendekatan Particiopation action research (PAR), Program ini dititikberatkan kepada membangun kesadaran pendidikan anak di lingkungan perkampungan transisi kota dengan melakukan workshop pengabdian kepada masyarakatdan melakukan pemberdayaan kepada para remaja melalui kegiatan life skill education berupa keterampilan-keterampilan yang tidak banyak mereka dapat di sekolah formal.

Kata Kunci: PAR, pendidikan anak, lingkungan perkampungan 


\section{PENDAHULUAN}

Badegan "Remaja hari ini adalah pemimpin bangsa hari esok" kalimat tersebut merupakan sebuah pepatah Arab kuno yang sudah banyak diketahui maksud dan artinya. Kalimat bijak di atas menjelaskan bahwa para remaja atau para pemuda merupakan generasi bangsa yang mampu memimpin dan meneruskan perjuangan bangsa ini. Kalimat bijak ini juga memberikan penegasan bahwa masa depan sebuah bangsa dapat diprediksi dengan cara melihat kondisi para pemuda saat ini. Dalam konteks Indonesia, dapat disimpulkan bahwa ketika para remaja bangsa ini mempunyai kekuatan fisik, mental, dan spiritual yang kokoh, niscaya kehidupan negara Indonesia beberapa tahun mendatang akan kuat, makmur, dan sejahtera. Sebaliknya, bila kondisi remaja saat ini lemah fisik dan mental serta miskin spiritual, rasanya sulit Indonesia dapat memenangkan persaingan global yang kian ketat. Oleh sebab itu, perhatian terhadap kehidupan remaja merupakan salah satu langkah tepat untuk mengantarkan bangsa ini menjadi bangsa yang diperhitungkan dalam percaturan internasional.

Sebenarnya, telah banyak program pemerintah yang diluncurkan untuk pemberdayaan masyarakat di berbagai wilayah, termasuk di daerah tertinggal. Bantuan langsung tunai, kredit usaha kecil, hingga pendidikan gratis untuk program wajib belajar 9 tahun (pelajar SD dan SMP) sudah sering terdengar. Namun sayang, dalam tataran praktik, berbagai penyimpangan acapkali terjadi yang disebabkan oleh beragam alasan. Oleh karena itu, tidak sedikit remaja yang hidup dalam kondisi memprihatikan dan terjebak dalam lingkaran kemiskinan. Mereka menjadi generasi yang tidak hanya miskin ketrampilan untuk bertahan hidup, tetapi juga miskin ilmu pengetahuan dan keagamaan.

Pendidikan sejatinya menjadi sebuah aset bagi kemajuan suatu bangsa terutama bagi bangsa Indonesia. Setiap warga Indonesia diwajibkan mengikuti jenjang pendidikan, mulai dari jenjang pendidikan dini, dasar, menengah dan jenjang pendidikan tinggi. Kewajiban mengikuti jenjang pendidikan ini sebagaimana diamanahkan oleh undang-undang dasar tahun 1945 pada pasal 31 ayat 1 dan ayat 2. Pasal 31 ayat menyebutkan bahwa setiap warga Negara berhak mendapatkan pendidikan. Pasal 31 ayat 2 menjelaskan setiap warga Negara wajib mengikuti pendidikan dasar dan pemerintah menanggung biayanya.

Di dalam undang-undang nomor 20 tahun 2003 tentang sistem pendidikan nasional dijelaskan bahwa pendidikan adalah usaha sadar dan terencana untuk mewujudkan suasana belajar dan proses pembelajaran agar peserta didik secara aktif mengembangkan potensi dirinya untuk memiliki kekuatan spiritual 
keagamaan, pengendalian diri, kepribadian, kecerdasan, akhlak mulia, serta keterampilan yang diperlukan dirinya, masyarakat, bangsa dan negara.

Pada dasarnya hak dan kewajiban pendidikan telah dijamin oleh undangundang, akan tetapi secara faktual bisa dilihat bahwa pendidikan di Indonesia belum berjalan secara maksimal. Masih banyak dijumpai anak-anak yang putus sekolah. Berdasarkan data UNICEF tahun 2014 masih dijumpai sebanyak 2,5 juta anak Indonesia tidak dapat menikmati pendidikan lanjutan yakni sebanyak 600 ribu anak usia Sekolah Dasar (SD) dan 1,9 juta anak usia Sekolah Menengah Pertama (SMP).

Dari data statistik tingkat provinsi dan kabupaten menunjukkan bahwa terdapat kelompok anak-anak tertentu yang terkena dampak paling rentan yang sebagian besar berasal dari keluarga miskin sehingga tidak mampu melanjutkan pendidikan ke jenjang selanjutnya. Anak-anak yang berasal dari keluarga kurang mampu, memiliki kemungkinan putus sekolah emapat kali lebih besar daripada mereka yang berasal dari keluarga berkecukupan. Untuk data statistik geografis, tingkat putus sekolah anak pada tingkat Sekolah Dasar di desa 3:1 dibandingkan dengan di daerah perkotaan. Hal tersebut terjadi karena dipicu oleh faktor kekurangan tenaga pengajar untuk daerah terpencil dan tergolong berpenghasilan rendah. Tingkat putus sekolah anak di desa dapat mencapai 3\% jika dibandingkan dengan anak di perkotaan. Keadaan seperti ini seharusnya menjadi perhatian pemerintah dalam pemerataan pendidikan di Indonesia (Mujtahidien, 2015).

Kebanyakan dari masyarakat yang putus sekolah adalah disebabkan karena faktor ekonomi dan lingkungan. Faktor ekonomi disebabkan karena masyarakat tidak mampu membiayai pendidikan anaknya kejenjang yang lebih tinggi. Biasanya anak yang putus sekolah akibat orang tuanya tidak mampu membiayai sekolah terjadi pada transisi ketika anak tamat pada tingkat Sekolah Dasar menuju tingkat Sekolah Menengah Pertama. Akibatnya anak-anak yang putus sekolah ini memilih memilih menjadi pengamen, pengemis, main-main yang tidak jelas arah perkembangannya. Menurut Retno Listyarti (news.okezone.com, 2015), merujuk data Forum Serikat Guru Indonesia (FSGI) angka anak putus sekolah terutama terjadi pada anak perempuan di usia 7,7 tahun atau anak yang sudah memasuki bangku Sekolah Dasar ke Sekolah Menengah Pertama dan hal ini hampir terjadi di sebagian besar provinsi, terutama di daerah tertinggal. Adapun, untuk anak putus sekolah khusus laki-laki di usia 8,1 tahun saat memasuki Sekolah Menenga Pertama (news.okezone.com, 2015). Sehingga bisa dikatakan bahwa keadaan status ekonomi keluarga miskin cenderung akan menimbulkan berbagai masalah yang berkaitan dengan pembiayaan hidup anak, 
khususnya dalam pendidikan anak, sehingga anak sering dilibatkan untuk membantu memenuhi kebutuhan ekonomi keluarga sehingga merasa terbebani dengan masalah ekonomi ini sehingga mengganggu kegiatan belajar dan kesulitan mengikuti pelajaran.

Sementara itu, faktor lingkungan sendiri disebabkan karena oleh pengaruh yang disebabkan oleh lingkungan tempat seseorang. Misalnya ketika seseorang tinggal di masyarakat yang mayoritas tidak berpendidikan maka dia akan terpengeruh oleh masyarakat tersebut dan memiliki kecenderungan lebih tinggi akan terbawa pada budaya tidak perduli pada pendidikan.

Masalah putus sekolah sebagaimana data di atas juga dialami di daerah kecamatan Cipocok, khususnya di desa Tegal Jeruk Kota Serang. Lokasi Desa Tegal Jeruk Kecamatan Cipocok Kota Serang sebenarnya tidak begitu jauh dari wilayah Kota Serang. Jarak desa ini hanya sekitar kurang lebih $3 \mathrm{~km}$ berdekatan dengan kantor Walikota Serang. Namun berdasarkan data dari kelurahan setempat diketahui bahwa mayoritas penduduk desa ini tergolong ekonomi miskin. Mayoritas penduduk bekerja sebagai buruh kasar. Sebagian penduduk desa ini menjalani profesi sebagai kuli bangunan, sopir angkot, pedagang asongan, karyawan pabrik, dan sebagian ada yang bertani. Keadaan ekonomi yang dialami penduduk desa ini sedikit banyak mempengaruhi tingkat kepedulian untuk menyekolahkan anak mereka kejenjang pendidikan yang lebih tinggi. Kebanyakan orang tua lebih sibuk mengurusipemenuhan kebutuhan hidup sehari-haridibandingkan mengurusi kebutuhan pendidikan anak-anaknya. Kemudian dari kesibukan mencari pemenuhan kebutuhan hidup inianak-anak pun ikutmembantu orang tuanya mencari tambahan ekonomi keluarga.

Kondisi demikian mengakibatkan minimnya kesadaran dari orang tua untuk menyekolahkan anaknya pada jenjang pendidikan yang lebih tinggi. Berdasarkan pre-riset dan pelaksanaan kegiatan pemberdayaan ditemukan adanya beberapa faktor yang mempengaruhi kesadaran orang tua terhadap pendidikan anaknya. Beberapa faktor tersebut adalah pertama, stigma masyarakat yang menganggap bahwa pendidikan itu mahal, kedua, pesimisme masyarakat terhadap anak sekolah yang dianggap tidak mampu memperoleh pekerjaan setelah menyelesaikan pendidikan sekolahnya. Ketiga, rendahnya jenjang penidikan yang dimiliki menjadikannya tidak terbuka dengan pengaruh positif yang dihasilkan oleh pendidikan.

Kemudian dilihat dari faktor lingkungan juga masih dijumpai masyarakat yang belum memiliki kesadaran kolektif tentang bagaimana cara mendidik anak yang baik. Masyarakat menyekolahkan anaknya ke sekolah hanya sekedar mengikuti kebiasaan teman-temannya. Anak-anak tidak diperhatikan bagaimana 
perkembangan penddidikannya, prestasi apa yang dicapai, dan kebutuhan apa yang perlu dilengkapi untuk pendidikan anak-anaknya. Lingkungan merupakan segala sesuatu yang ada disekitar anak baik berupa benda-benda, peristiwaperistiwa, yang terjadi, maupun kondisi masyarakat lingkungan di mana proses pendidikan berlangsung dan lingkungan di mana anak-anak bergaul setiap hari. Menurut Sartain (ahli psikologi Amerika), sebagaimana dikutip M.Ngalim Purwanto dalam bukunya yang berjudul Ilmu Pendidikan Teorotis dan Praktis, yang dimaksud dengan lingkungan (environment) meliputi kondisi dan alam dunia ini yang dengan cara-cara tertentu mempengaruhi tingkah laku seseorang, pertumbuhan, perkembangan atau life processes (Purwanto, t. th).

Kemudian jika dilihat dari lokasi, desa ini seharusnya sudah maju dalam bidang pendiddikannya. Karena letak geografis desa ini yang dekat dengan kantor wali Kota Serang. Disamping lokasinya yang dekat dari Wali Kota Serang, desa ini juga berdekatan dengan pusat lembaga lembaga pendidikan yang terkenal seperti Institut Agama Islam Negeri (IAIN) Sultan Maulana Hasanuddin yang berlokasi di Kota Serang dan Universitas Sultan Agung Tirtayasa (UNTIRTA). Dilihat dari potensi letak georafis tersebut selayaknya desa Tegal Jeruk ini seharusnyamemilikitingkat kesadaranyang tinggi dalam menyekolahkan anaknya kejenjang yang lebih tinggi. Kemudian juga seharusnya mampu memotivasi anak dalam meraih cita-cita dengan mengikuti pendidikan setinggi mungkin. Bukan sebaliknya menjadikan masyarakat dan anak-anak jauh dari pendidikan.

Namun jika ditelaah secara lebih mendalam dari kondisi tersebut, mengapa ada ketimpangan pendidikan dengan desa lain yang bertetanggaan dengan desa ini - memang banyak sekali-faktor yang menjadi penyebabnya. Diantaranya adalah faktor kemiskinan dan belum adanya penyadaran pada masyarakat. Selain faktor kemiskinanadalah minimnya peran pemerintah, dalam hal ini Wali Kota Serang, Kelurahan, dan Kecamatan dalam melihat kondisi pendidikan di desa ini.

\section{POTENSI DAN PERMASALAHAN}

Berasarkan pada observasi awal dilihat bahwa kondisi masyarakat masih tertinggal baik secara ekonomi, pekerjaan, dan pendidikan. Masyarakat desa ini belum mampu menciptakan kondisi ekonomi yang mapan. Mayoritas masyarakat hanya mengandalkan tenaganya dalam mencari sumber-sumber ekonomi dalam mencukupi penghidupannya. Masyarakat desa ini belum mampu 
menciptakan peluang sendiri dalam memenuhi kebutuhan ekonomi. Faktor rendahnya pendidikan menjadi penyebab utama kondisi tersebut.

Hal demikian mengakibatkan anak-anak mengikuti pola dari orang tuanya. Faktor orang tua yang tidak memperdulikan pendidikan pada akhirnya menyebabkan anak-anak kurang berminat melanjutkan sekolah kejenjang yang lebih tinggi. Anak-anak tidak memiliki tujuan dan arah yang jelas mau ke mana setelah lulus Sekolah Dasar (SD). Kemudian juga bagi yang sudah menyelesaikan Sekolah Menengah Pertama atau Sekolah Menengah Atas belum mampu menjangkau pekerjaan yang memadai. Dan alasan ini yang membuat anak-anak kurang berminat melanjutkan sekolah kejenjang yang lebih tinggi. Ditambah stigma dari orang tua bahwa bersekolah itu menghabiskan banyak biaya dan mahal dan tidak menjamin langsung bisa bekerja karena setelah lulus masih sulit mencari pekerjaan dan malah akan membebani orang tua.

Dengan adanya program pendampingan ini. masyarakat diharapkan mulai memiliki tingkat kesadaran pada dunia pendidikan. Dengan adanya program pendampingan ini juga diharapkan menjadi solusi bagi masyarakat dalam menjembatani kesulitan ekonomi dalam menyekolahkan anak-anaknya. Program ini memberikan ketrampilan bagi anak-anak Sekolah Menengah Pertama dan Sekolah Menengah Atasa supaya memiliki skill di bidang ketrampilan.

Kemudian dari hasil program ini diharapkan akan meningkatkan kesadaran anak-anak dalam memasuki jenjang pendidikan. Anak-anak merasa senang karena telah dibekali ketrampilan-ketrampilan untuk membantu orang tua dalam pendidkan.

\section{STRATEGI DAN METODE}

Jenis data dan informasi terdiri dari data dan informasi primer dan sekunder. Pengumpulan data dan informasi primer dilakukan dengan metode survai pendasaran (baseline survey) dan pemahaman desa secara partisipatif (participatory action research/PAR). Survai pendasaran dilaksanakan melalui wawancara terhadap masyarakat serta pengamatan lapangan langsung (direct observation). Sementara itu pelaksanaan PAR ditempuh sesuai dengan spesifikasi kaidah dan prinsipnya, yakni melibatkan aspirasi peran serta (partisipasi) masyarakat.

Dalam kajianparticipatory action research sekurang-kurangnya terdapat enam jenis pendekatan, yakni formatif, perbaikan sistem (system improvement), penyelesaian masalah (problems solving), analisis model (model analysis), peran serta (participatory), dan kesadaran kritis (critical corporate self-consciousness). Pendekatan yang dilakukan dalam kajian tindakan ini adalah penyelesaian masalah (problems 
solving) dan peran serta (participatory), karena dianggap paling relevan dengan upaya pemberdayaan masyarakat.

Sedangkan strategi yang digunakan dalam melakukan program ini adalah dengan memobilisasi sumber daya manusia dan potensi lokal, dalam hal ini adalah tim pemberdayaan yang menjadi penggerak dalam membangun kesadaran masyarakat terhadap pentingnya pendidikan. Beberapa langkah dan upaya membangun kesadaran masyarakat terhadap pendidikan sudah dilakukan seperti, workshop membangun kedasaran pendidikan terhadap masyarakat, pendampingan belajar agama, memberikan beasiswa pada anak-anak yang putus sekolah, dan memberikan ketrampilan life skill. Dengan strategi ini diharapkan dapat mengatasi problematika yang ada pada subyek dampingan. Demikian pula dengan alternatif pemecahan masalahnya adalah didiskusikan bersama-sama dengan subjek dampingan.

Adapun dalam implementasinya, program ini telah dilakukan metodemetode sebagai berikut: a) Melakukan pemetaan ulang dan identifikasi masalah terhadap problem yang dihadapi masyarakat, khususnya dalam mengatasi masalah ekonomi dan pengangguran anak-anak selain itu juga dilakukan pemetaan peluang serta kekuatan yang diharapkan dapat dijadikan solusi alternatif terhadap permasalahan tersebut, b) Focus Group Discussion dan analisis masalah (collective meeting), c) Tahap persiapan aksi program sesuai dengan hasil analisis masalah yang dilakukan bersama para subyek dampingan, d) Sosialisasi Program, e) Pelaksanaan Program, f) Monitoring, Dan g) Evaluasi Program.

\section{PROGRAM DAN PENGELOLAAN SUBSTANTIF}

Adapun program dalam kegiatan pengabdian masyarakat berbasis PAR ini dititikberatkan kepada membangun kesadaran pendidikan anak di lingkungan perkampungan transisi kota dengan melakukan workshop pengabdian kepada masyarakat dengan tema "upaya membangun kesadaran pendidikan,dan melakukan pemberdayaan kepada para remaja melalui kegiatan life skill education berupa keterampilan-keterampilan yang tidak banyak mereka dapat di sekolah formal.

Pada substansinya program pemberdayaan ini dikelola berdasarkan pada partisipasi dan keputusan bersama antara tim pemberdayaan dan pihak lain yang mendukung. Alur pengelolaan program secara berurutan meliputi; penjajakan, perencanaan kegiatan, pelaksanaan kegiatan, monitoring, dan evaluasi kegiatan.

Program ini diawali dengan "penjajagan kebutuhan" yang dilakukan oleh tim pemberdayaan sebagai pengusul dan masyarakat desa Tegal Jeruk sebagai 
subjek dampingan. Penjajagan kebutuhan dikerjakan melalui silaturrahim, observasi dan wawancara. Yang dilanjutkan dengan "perencanaan kegiatan" dilakukan oleh tim pengusul dan masyarakat dampingan serta pihak lain yang berkaitan hingga menghasilkan "bentuk kegiatan" dalam bentuk focus group discution (collective meeting). "Pelaksanaan kegiatan" dilaksanakan bersama antara tim pengusul dan masyarakat dampingan. Dalam pelaksanaan kegiatan, tim pengusul sebagai pendamping dan masyarakat dampingan sebagai subyek kegiatan. "Monitoring kegiatan" dilakukan oleh tim pengusul bersama Lembaga Pusat Pengabdian kepada Masyarakat LP2M IAIN SMH Banten dan diakhiri dengan evaluasi kegiataan dikerjakan bersama-sama antara tim pengusul dan masyarakat dampingan. Dengan demikian, perubahan sosial melalui transformasi sosial tampak dari pemberdayaan yang dilakukan secara partisipatoris.

Pendidikan merupakan modal utama untuk mempersiapkankehidupan di zaman yang penuh persaingan seperti saat ini. Di zaman modernisasi dan globalisasi seperti saat ini dibutuhkan keterampilan, wawasan dan pengetahuan yang luas, agar kita bisa bersaing di dunia pendidikan maupun dunia kerja. Tiga hal tersebut bisa diperoleh melalui lembaga pendidikan. Lembaga pendidikan merupakan lembaga utama pengembangan pengetahuan, melatih kemampuan dan keahlian, menanamkan sikap modern pada individu, dan masih banyak hal yang kita dapatkan dalam bangku pendidikan tersebut. Sesuai dengan peran pendidikan sebagai engine of growth, dan penentu bagi perkembangan masyarakat, maka anak(termasuk usia remaja) diharapkan mampu membawa masyarakat umum kearah perkembangan yang positif, karena anak (usia remaja) merupakan ujung tombak bagi perkembangan pembangunan nasional.

Namun, masih banyak warga Indonesia yang masih acuh tak acuh mengenai pentingnya pendidikan bagi kehidupannya. Masyarakat yang belum menyadari pentingnya pendidikan akan menjadi masyarakat yang minim pengetahuan, kurang keterampilan, dan kurang keahlian. Mereka akan menjadi masyarakat yang tertinggal dan terbelakang karena mereka tidak bisa menyesuaikan kemajuan zaman.

Orang yang berpendidikan tidak akan mempunyai pemikiran-pemikiran yang sempit mengenai masa depan, mereka berorientasi dengan masa depannya. Orang yang berpendidikan juga akan hidup dengan norma-norma yang berlaku dalam masyarakat. Mereka tahu apa yang akan dilakukan dengan masa depannya, tidak akan menyerah atau pasrah dengan keadaan. Sebaliknya, Orang-orang atau orang tua yang mempunyai jalan pikiran sempit yang menganggap pendidikan tidak penting, mengakibatkan anak-anak mereka yang tidak mengenyam pendidikan formal akan menjadi beban bagi masyarakat bahkan sering menjadi 
pengganggu ketentraman masyarakat. Hal ini diakibatkan oleh kurangnya pendidikan atau pengalaman intelektualnya, serta tidak memiliki keterampilan yang menopang kehidupan sehari-hari.

Orang-orang tersebut kebanyakan ditemukan di desa-desa pelosok atau di daerah-daerah terpencil. Menurut Dalyono (2008), rendahnya minat orang tua terhadap pendidikan disebabkan oleh beberapa faktor, misalnya faktor pribadi (tingkat kesadaran), faktor ekonomi, faktor sosial budaya (social cultur), dan faktor letak geografis lembaga pendidikan.

Kesadaran merupakan suatu bagian terkecil dari keseluruhan pikiran manusia. Freud menjelaskan bahwa alam sadar adalah satu-satunya bagian yang memiliki kontak langsung dengan realitas kehidupan. Cartesianlike menyebutkan bahwa diri adalah bagian dari mental dan sebuah substansi material yang berfungsi eksekutif bagi seorang individu, menyerap informasi, dan mendorong tubuh untuk melakukan sebuah perilaku untuk mempengaruhi lingkungan. Fungsi eksekutif dalam hal ini ialah diri sebagai sumber alasan dan pikiran dari apa yang dilihat dan dirasakan oleh seorang individu. Kesadaran dalam berpendidikan merupakan hal yang fundamental dalam kehidupan manusia. Pendidikan dapat menjadi indikator tingkat kehidupan sosial dalam masyarakat. Kesadaran pendidikan mempengaruhi tingkat pendidikan seseorang, semakin tinggi pendidikanya semakin tinggi pula status sosial yang didapat dalam masyarakat.

Lebih lanjut Firdaus (2005) menyebutkan bahwa rendahnya minat orang tua untuk melanjutkan pendidikan anaknya ke Sekolah Menengah Pertama disebabkan: Pertama, faktor sosial budaya sebesa Kedua, faktor kurangnya biaya pendidikan (ekonomi tidak mampu), danketiga, faktor kurangnya tingkat kesadaran orang tua akan pentingnya pendidikan (faktor orang tua) Keempat, letak geografis sekolah. Jadi faktor ekonomi bukan penyebab utamanya, ada juga faktor pribadi (tingkat kesadaran), faktor sosial budaya (social cultur), dan faktor letak geografis sekolah juga bisa menyebabkan rendahnya minat pendidikan pada masyarakat.

\section{TAHAPAN-TAHAPAN PELAKSANAAN PROGRAM PAR}

Implementasi program PAR dalam kegiatan membangun kesadaran pendidikan pada anak-anak di daerah transisi kota atau masyarakat termarginalkan di dusun Tegal Jeruk Desa Banjar Agung Kecamatan Cipocok Jaya sudah dilaksanakan dengan berbagai kegiatan. Diantara kegiatan yang dilaksanakan yaitu kegiatan penyadaran masyarakat melalui sosialisasi dari tokoh 
masyarakat, kegiatan penyadaran pendidikan melalui pengajian-pengajian. Dalam kegiatan penyadaran melalui kegiatan pengajian, sudah dilaksabakan oleh lembaga pendidikan Laksita yaitu yayasan yang berlokasi di dusun Tegal Jeruk.

Sebagaimana yang sudah berjalan, beberapa kegiatan pendidikan di lembaga Laksita adalah, pertama, pengajian al-Quran yang dilaksanakan setiap hari setelah shalat Maghrib. Kedua, kegiatan pendalaman bahasa Inggris dan Bahasa Arab. Walaupun kegiatan tersebut dilaksanakan secara gratis, masyarakat belum sepenuhnya merespon. Hanya terlihat beberapa anak yang mengikuti kegiatan tersebut.

Tahap pertama: Melakukan Focus Group Discussion dan analisis masalah (collective meeting) pertama, bersama dengan masyarakat dan tokoh masyarakat setempat. Kegiatan ini dilakukan dalam rangka menelusuri permasalahan dan sekaligus menemukan potensi masyarakat Dusun Tegal Jeruk. FGD pertama dilaksanakan pada tanggal 17 Juli 2015 bertempat di Yayasan Laksita. Dalam kegiatan ini tim pendamping melakukan sharing langsung dengan warga. Dalam sharing ini banyak ditemukan permasalahan-permasalahan yang dihadapi warga terkait pendidikan.

Sebagaimana penjelasan tokoh masyarakat dusun Tegal Jeruk bapak Syamsuri (ketua RT) mengatakan, bahwa kebanyakan dari anak-anak di dusun Tegal Jeruk tidak melanjutkan pendidikan ke jenjang yang lebih tinggi. Kebanyakan anak-anak hanya berpendidikan sampai Sekolah Dasar. Anak-anak lebih memilih untuk menjadi pengamen, sebagian anak ada yang memilih membantu pekerjaan orang tuanya, dan juga ada yang tidah memahami apa tujuan sekolah dan hanya bermain-main dan berkumpul-kumpul.

Kemudian dalam kegiatan sharing dengan masyarakat juga terdapat masukan-masukan dan keluhan, diantaranya adalah dari orang tua anak, Ibu Royani yang mengatakan, "kami di sini memang begini kondisinya pak, kebanyakan dari kami adalah orang miskin, terus banyak dari kami yang ekonominya pas-pasan. Bahkan hanya sekedar untuk mencukupi kebutuhan sehari-hari saja masih kurang. Sehingga dalam mengurus pendidikan anak-anak kejenjang yang lebih tinggi, memang kami belum mampu".Kemudian bapak Rahman menambahkan, bahwa "pendidikan cukup lulus pada tingkat Sekolah Dasar saja, karena setelah lulus Sekolah Dasar anak-anak harus membantu orang tua mencari penghidupan". Sedangkan ibu Jamilah mengatakan, bahwa "pendidikan tinggi juga tidak menjamin anak bisa mendapat pekerjaan, seperti anak saya ini pak, sudah lulus SMK tapi belum mendapat pekerjaan yang layak".

Dari kegiatan Focus Group Discussion pertama ini bisa disumpulkan bahwa persoalan mendasar yang dialami masyarakat Tegal Jeruk dalam rangka 
membangun kesadaran pendidikan bagi anak-anak mereka adalah pada persoalan kemiskinan. Faktor kemiskinan membuat para orang tua tidak memiliki kepekaan terhadap keberlanjutan pendidikan anak-anak mereka. Kemudian dari kondisi ini juga mengakibatkan budaya masyarakat Tegal Jeruk yang merasa pendidikanbelum dianggap penting dan anak-anak tidak berpendidikan dianggap biasa.

Kemudian setelah dilakukan sharing mengenai permasalahan-permasalahan dibidang keberlanjutan pendidikan anak-anak dalam FGD pertama ini didapatkan sebuah kesepakatan bersama mengenai langkah-langkah solutif bagi masyarakat Tegal Jeruk. Beberapa kesepakatan yang dibangun antara tim pendamping bersama masyarakat adalah dengan pembentukanprogram pemberdayaan keterampilan bagi masyarakat.

Sebagaimana yang diungkapkan oleh Syamsuri (ketua RT), saya selaku ketua RT di dusun Tegal Jeruk ini sangat mendukung program pemberdayaan masyarakat yang diprakarsai dari tim pendamping IAIN. Program ini sangat bermanfaat bagi warga kami mengingat kondisi ekonomi masyarakat kami yang belum mapan dan juga kondisi masyarakat yang hamper mayoritas berpendidikan rendah. Keinginan tersebut kemudian direspon dalam kegiatan pelatihan pemberdayaan pendidikan keterampilan bagi masyarakat, khususnya adalah pendidikan keterampilan bagi anak-anak usia sekolah, yaitu dengan memberikan pemahaman kepada mereka bahwa pendidikan dalam bentuk apapun, baik dalam bentuk pendidikan formal maupun pendidikan non formal sangat penting dalam membentuk sikap hidup seseorang.

Hal sebagaimana disampaikan oleh ustaz M. Nur Arifin selaku tim anggota tim pendamping dan sekaligus ketua yayasan Laksita dalam kegiatan FGD I. Dikatakan bahwa "bapak-bapak dan ibu-ibu jangan khawatir tentang biaya pendidikan, program pemerintah saat ini sudah banyak yang menggeratiskan pendidikan baik ditingkat SD sampai ketingkat SMA, ibu-ibu dan bapak-bapak, yang dibutuhkan saat ini adalah kesadaran kita semua tentang betapa pentingnya pendidikan bagi anak-anak kita, yang merupakan generasi penerus perjuangan kita ke depan. Pendidikan sangat penting untuk mencapai keberhasilan pada masa yang akan datang. Insya Alloh kami akan berupaya memberikan solusi mengenai bagaimana ke depan anak-anak kita bisa berdaya dalam pendidikan dan juga dalam bidang keterampilan. Salah satu bentuk dari kepedulian kami adalah adanya program penyadaran pentingnya pendidikan bagi anak-anak yang akan kita laksanakan nanti. Insya Allah bersama teman-teman kita akan melakukan pendampingan selama kurang lebih lima bulan yang akan berpusat di tempat saya ini yang juga kantor yayasan Laksita”. 
Minat masyarakat dalam program pemberdayaan yang disepakati bersama menjadi satu dukungan yang potensial bagi pengembangan masyarakat, khususnya bagi anak-anak memiliki keterampilan. Dalam FGD pertama ini juga disepakati bahwa pendampingan program pemberdayaan diserahkanan kepada yayasan Laksita. Karena menurut sebagian wargayayasan Laksita selama ini sudah memiliki peran aktif dalam mendampingi anak-anak yang hampir putus sekolah.

Tahap Kedua: Melakukan Focus Group Discussion kedua(collective meeting) bersama dengan masyarakat dan tokoh masyarakat setempat. Kegiatan ini dilakukan dalam rangka menindak lanjuti FGD yang pertama yaitu menyepakati adanya program pemberdayaan bagi masyarakat dalam bidang keterampilan bagi anak-anak. Dalam kegiatan FGD kedua ini juga dibahas mengenai bidang pemberdayaan yang dipilih. Ada banyak usulan mengenai bidang pemberdayaan yang tepat untuk dilaksanakan. Salah satu usulan adalah dari bapak Syamsuri yang mengatakan, bahwa "program pemberdayaan di dusun kami yang tepat adalah membuat kerajinan dari bahan lidi, hal ini saya usulkan karena di wilayah kita terdapat banyak pohon-pohon kelapa, sehingga alangkah tepat jika kita manfaatkan potensi alam yang ada".

Hal yang sama juga di sampaikan oleh Cipto, yang mengatakan bahwa "disamping faktor potensi pohon kelapa yang banyak di wilayah kita, perlu dilihat juga peluang pemberdayaan keterampilan dari bahan lidi cukup bagus dari segi kebutuhan masyarakat, sehingga hasil kerajinan berbahan lidi nanti akan diminati oleh masyarakat kita”. Kemudian ustaz Moh. Arifin, selaku ketua Yayasan Laksita juga mengusulkan program pemberdayaan yang berbahan kertas bekas atau koran. Menurut ustaz Moh. Arifin, "saya punya pengalaman waktu pendampingan Kukerta di wilayah Mandalawangi, mahasiswa mengadakan program pemberdayaan keterampilan dari bahan kertas, Insya Alloh nanti saya akan coba mengundang tim dari mahasiswa untuk melatih keterampilan berbahan kertas bekas koran ini. Disamping itu saya juga punya relasi dengan teman yang cukup ahli dibidang ini di Jakarta. Nanti saya utus beberapa anak untuk mengikuti pelatihan pembuatan bahan kerajinan kertas ke Jakarta". Selanjutnya ustaz Arifin juga menawarkan satu lagi program pemberdayaan budi daya jamur. Karena menurut ustaz Moh. Arifin upaya budi daya Jamur sangat cocok untuk warga Tegal Jeruk, karena prosesnya yang sangat mudah dan iklimnya cocok di Tegal Jeruk.

FGD keduayang dilaksanakan padatanggal 10Agustus 2015 bertempat di Yayasan Laksita ini akhirnya menyepakati tiga bidang pemberayaan kerajinan, yaitu budi daya jamur, kerajinan berbahan lidi, dan kerajinan tangan berbahan 
koran beka. Adapun hasil FGD kedua secara rinci adalah sebagai berikut: Pertama, adanya kesadaran dan kesepahaman antara yayasan Laksita, RT, dan masyarakat bahwa di dusun Tegal Jeruk perlu ada lembaga khusus yang mengelola pemberdayaan dalam bidang keterampilan pada masyarakat, khususnya pemberdayaan pada anak-anak usia sekolah Dasar dan Sekolah Menengah.

Kedua, sebelum dibentuk program pemberdayaan keterampilan harus dilakukan pelatihan terlebih dahulu, khususnya kepada anak-anak yang secara langsung bisa mengikuti pelatihan.

Ketiga, peran tim pengabdian dari IAIN SMH Banten dalam pelatihan tersebut adalah sebagai fasilitator dan sekaligus sebagai pendamping dalam pengelolaan sumberdaya keterampilan dan sekaligus sebagai evaluator setelah program pemberdayaan pendidikan keterampilan berjalan.

Keempat, informasi dari masyarakat, bahwa kondisi masyarakat dusun Tegal Jeruk masih rendah dalam pendidikan dan keresahan tentang mahalnya pendidikan yang belum bisa dijangkau oleh masyarakat. Kemudian mayoritas masyarakat tidak memiliki keahlian dalam bidang usaha yang bisa menopang kesejahteraan ekonomi masyarakat.

Kelima, disepakati bersama oleh seluruh peserta rapat, bahwa pelatihan tentang pemberdayaan keterampilan akan dilaksanakan pada hari minggu ketiga bulan Agustus 2015 yang bertempat di yayasan Laksita dengan kepanitiaan yang dipilih oleh masyarakat atas arahan ketua yayasan Laksita, yaitu:

$\begin{array}{lll}\text { - } & \text { Syamsuri } & \text { (Ketua RT dusun Tegal Jeruk) } \\ \text { - Ali Dzikri } & \text { (Sekretaris) } \\ \text { - } & \text { M. Nur Arifin } & \text { (Bendahara) } \\ \text { - } & \text { Cipto } & \text { (Anggota) }\end{array}$

Keenam, Pemateri workshop adalah tim ahli dari Jakarta dan tim pendamping dari program PPM LP2M IAIN SMH Banten.

Tahap Ketiga: melaksanakan kegiatan program pemberdayaan berbasis pada keterampilan. pemberdayaan masyarakat bertujuan memberdayakan (empowering) kelompok masyarakat yang tidak berdaya. Dalam mengimplementasikan kegiatan pemberdayaan difokuskan pada peningatakan kapasitas masyarakat dalam pengelolaan sumber daya yang ada dalam masyarakat. Sebagaimana kesepakatan pada FGD kedua, bahwa solusi membangun kesadaran pendidikan salah satunya juga perlu adanya pembekalan keterampilan. Sehingga keputusan pemberdayaan yang difokuskan pada anak-anak adalah bidang keterampilan budi 
daya jamur, program keterampilan berbahan lidi, dan program kerajinan berbahan koran bekas.

Kegiatan keterampilan ini dilaksanakan setelah anak-anak dibekali keterampilan bagaimana cara membuat kerajinan tangan dengan baik. Mereka mengerjakan kegiatan keterampilan ini dengan sungguh-sungguh dan sangat serius. Dari mulai pelaksanaan kegiatan awal sampai saat ini kegiatan keterampilan kerajinan tangan masih berjalan. Beberapa kegiatan yang sudah berjalan adalah keterampilan membuat kerajinan tangan berbahan kertas, dan kerajinan tangan berbahan lidi. Sedangkan untuk budi daya jamur sudah dilakukan cara membudi dayakannya namun masih dalam proses penyiapan alat dan tima ahli dibidangnya.

Tahap Keempat: Melaksanakan workshop tentang upaya membangun kesadaran masyarakat dalam bidang pendidikan yang diikuti oleh tokoh masyarakat, dan warga yang telah diundang oleh ketua RT dusun Tegal Jeruk. Pemateri workshop adalah Dr. Nana Jumhana, M.Ag (ketua tim pengabdian program PPM LP2M IAIN SMH Banten) yang juga sebagai wakil dekan bidang akademik di Fakultas Tarbiyah dan Keguruan IAIN SMH Banten. Kemudian pemateri kedua dalam workshop ini adalah Drs. H. M. Luthfi, M.Ag yang memiliki keahlian dalam memberikan spirit kepada masyarakat mengenai kesadaran dalam pendidikan bagi masyarakat, dikarenakan ustaz Drs. H. M. Luthfi, M.Ag adalah seorang dosen bidang pendidikan agama Islam beliau juga seorang penceramah kondang di wilayah Serang dan sekitarnya. Workshop ini dilaksanakan sehari penuh, yaitu dilaksanakan di Musholla dusun Tegal Jeruk pada hari Sabtu, tanggal 30 Oktober 2015 dengan materi pembahasannya tentang: "Upaya Membangun Kesadaran Pendidikan pada Masyarakat" Target dari kegiatan ini adalah: masyarakat memiliki pengetahuan dan pemahaman tentang pentingnya pendidikan bagi anak-anak.

Workshop mengenai upaya membangun kesadaran pendidikan ini sengaja dilaksanakan untuk para orang tua dengan tujuan supaya para orang tua memiliki kesadaran mengenai pendidikan bagi anak-anak mereka. Karena orang tua merupakan faktor terpenting dalam membangkitkan kesadaran pendidikan bagi anak-anaknya. Lingkungan keluarga sangat menentukan arah anak-anak dalam kegiatan pendidikan kejenjang pendidikan.

Adapun kesimpulan yang didapatkan dari pemaparan materi dan diskusi dengan peserta selama kegiatan workshop adalah:

a. Adanya pengetahuan tentang pentingnya pendidikan pada anak-anak.

b. Masa depan yang baik harus diraih melalui pendidikan. 
c. Islam sangat menganjurkan pada umatnya untuk mencari ilmu pengetahuan setinggi-tingginya

d. Perlunya keterampilan bagi anak-anak dalam rangka membangun etos wira usaha.

Tahap Kelima: FGD ketiga, yaitu diskusi dan Refleksi bersama. Kegiatan ini dilakukan untuk lebih mendalami dan memahami maksud dan keinginan warga bersama dengan tim pengabdian dalam melaksanakan program pemberdayaan pendidikan keterampilan.

Adapun hasil dari diskusi dan refleksi ini adalah: Warga mengevaluasi kegiatan pemberayaan keterampilan anak-anak. Masyarakat merasa senang dengan program pemberayaan ini yang secara langsung dikelola yayasan Laksita sebagai wadah tempat berlangsungnya kegiatan pelatihan dan tempat produksi hasil kerajinan dari anak-anak, karena menurut Syamsuri (Ketua RT), mengatakan bahwa "biarlah kegiatan pemberdayaan lebih fokus dan ada tempat yang longgar maka untuk seterusnya biarlah di yayasan Laksita". Usulan bapak Syamsuri selaku ketua RT nampaknya direspon oleh masyarakat sehingga mereka menyepakati bahwa untuk kegiatan pelatihan keterampilan selanjutnya setelah pendampingan yang dilaksanakan oleh tim pendamping biarlah tetap dilaksanakan di yayasan Laksita saja.

Tahap Keenam: adalah menentukan arah kedepan tentang upaya tindak lanjut. Yaitu bagaimana tindak lanjut mengenai kegiatan ini setelah selesai pendampingan dari tim pusat pengabdian kepada masyarakat IAIN SMH Banten. Dan bagaimana caranya melanjutkan program ke depan. Terus yang paling penting adalah menentukan langkah cara memasarkan produk setelah produk keterampilan anak-anak ini sudah dihasilkan.

Sehingga dalam FGD keempat disepakati bersama beberapa hal:

1. Dalam rangka keberlanjutan program. Diharapkan tim pendamping masih memberikan dukungan kepada masyarakat Tegal Jeruk, khususnya pendampingan kerajinan bagi anak-anak dampingan

2. Diharapkan jika ada program serupa dalam bentuk pemberdayaan dari pusat pengabdian kepada masyarakat IAIN SMH Banten supaya dialokasikan ke usun Tegal Jeruk.

3. Dalam rangka memasarkan produk hasil kerajinan tangan supaya dibantu untuk melakukan setrateginya.

4. Diharapkan yaysan Laksita sepenuhnya mendampingi keberlanjutan program ini. 


\section{EVALUASI DAN REFLEKSI}

Masyarakat yang ikut menjadi partisipan dalam kegiatan pengabdian ini memiliki latar belakang pendidikan yang berbeda-beda. Sebagian ada yang hanya lulusan SD (Sekolah Dasar). Ada pula yang hanya lulusan pada tingkat SMP (Sekolah Menengah Pertama) dan bahkan ada yang memiliki latar belakang pendidikan sebagai masyarakat putus sekolah. Usia merekapun menjadi faktor hambatan dalam melakukan pengabdian ini. Hal ini tentu agak menyulitkan pemateri dalam menyampaikan informasi. Namun dengan pendekatan yang lebih santai dan langsung praktik, para peserta nampaknya menikmati dalam mengikuti kegiatan tersebut.

Berbagai upaya pemberdayaan dalam kehidupan sosial bermasyarakat memiliki kendala yang berbeda-beda, namun bisa jadi kita dapatkan kendala yang sama. Setiap upaya pemberdayaan yang dilakukan akan berjalan dengan baik jika ada kerja-sama yang optimal dari semua pihak yang terlibat. Banyak faktor yang menyebabkan suatu upaya pemberdayaan dapat berjalan dengan maksimal atau tidak di antaranya adalah: ketersediaan dana, keterlibatan secara aktif para partisipan, adanya penggerak yang progresif, dan semua unsur yang dibutuhkan dalam tindakan pemberdayaan tersebut.

Dari beberapa tindakan partisipatif yang dilaksanakan, ada yang maksimal dan ada yang kurang maksimal. Salah satunya adalah upaya membangun semangat kebersamaan bagi para peserta program pemberdayaan keterampilan. Supaya kegiatan pemberdayaan ini bisa berjalan perlu adanya pendampingan yang berkelanjutan.

Kemudiam, kegiatan workshop dan pelatihan pemberdayaan keterampilan dirasa kurang maksimal hasilnya karena target dan tujuan dari kegiatan tersebut adalah memberikan pemahaman tentang bagaimana membangun ekonomi pada masyarakat, khususnya bagi anak-anak usia sekolah yang mandiri dan berbasis komunitas dengan harapan masyarakat bisa mengikuti program pelatihan semuanya. Ternyata dalam program pelatihan keterampilan ini hanya mampu menampung 15 anak saja. Namun harapan kami dengan adanya pembinaan yang diwakili oleh sementara anak yang berjumlah 15 ini akan bertambah banyak sehingga bisa diikuti oleh masyarakat secara umum.

Upaya pemberdayaan dalam kesadaran pendidikan di desa Tegal Jeruk Kecamatan Cipocokyang telah dilakukan sudah berjalan dengan baik. Hal ini disebabkan karena adanya kerja-sama yang baik antara tim pengusul kegiatan, yayasan Laksita, Pusat Pengabdian kepada Masyarakat (PPM) LP2M IAIN SMH Banten dan masyarakat setempat. Namun demikian ada beberapa hal yang perlu ditindak lanjuti dalam rangka peningkatan pemberdayaan ke depan, yang 
sekaligus menajdi rekomendasi dalam kegiatan pemberdayaan ini. Beberapa rekomendasi dan rencana tindak lanjut tersebut adalah:

Pertama, perlu adanya pendampingan berkelanjutan dalam memotivasi kesadaran agar memiliki kesadaran pendidikan. Keberlanjutan (sustainablity) pendampingan dapat dilakukan melalui kerjasama dengan yayasan Laksita yang notabene berada di lingkungan masyarakat yang menjadi subjek dampingan.

Kedua, perlu dilakukan pembinaan, khususnya anak-anak usia sekolah secara terfokus yang berbasis pada life skill education. Beberapa pembinaan yang terfokus pada life skill yang telah dilakikan oleh tim pengusul seperti budidaya bertanam jamur, membuat kerajinan berbahan lidi, dan membikin bahan kerajinan berbahan kertas koran, masih perlu ditambah dengan pembekalan ketrampilan lain sesuai dengan potensi masyarakat dampingan.

Ketiga, agar keterampilan yang telah mereka miliki tidak terhenti pada pada proses produksifitas, diperlukan upaya-upaya untuk membantu mereka dalam meningkatkan produksi kerajinan tangan yang dihasilkan, yaitu diperlukan strategi bantuan pemasaran terhadap produk-produk yang telah dihasilkan mereka.

Keempat, kegiatan life skill yang dilakukan ini bisa diikuti oleh masyarakat sekitar. Artinya perlu adanya program replikasi atau penularan dari program yang sedang diberdayakan pada masyarakat desa Tegal Jeruk ke desa-desa lain. Sehingga program life skill educatioan seperti ini banyak diberdayakan diseluruh masyarakat. Oleh karena itu segala bentuk bantuan dan dukungan dari lembaga pemerintah, swadaya masyarakat, dan pihak-pihak terkait sangat diharapkan demi tercapainya keberlanjutan (sustainability) program pemberdayaan masyarakt ini.

\section{KESIMPULAN}

Dari data yang didapatkan dari pembahasan di atas dapat ditarik beberapa kesimpulan. Pertama, Pendidikan dapat mengubah kondisi masyarakat menjadi lebih maju baik secara sosial dan ekonomi. Dengan pendidikan yang tinggi masyarakat akan memiliki wawasan yang luas untuk mengatur arah masa depan yang lebih baik. Kedua, Kondisi riil dusun Tegal Jeruk saat ini masih tertinggal secara pendidikan dan kesejahteraan. Kondisi riil ini diperparah dengan persepsi sebagian masyarakat yang belum memiliki kesadaran mengenai pentingnya pendidikan bagi anak-anak. Ketiga, Pemberdayaan program keterampilan bagi masyarakat khususnya pada anak-anak memiliki prospek yang cukup cerah karena didukung oleh kondisi masyarakat yang terus mengalami transformasi 
kearah yang lebih maju. Tinggal bagaimana menyiapkan tenaga di bidang manajemen yang ahli, dan lebih terampil. Dan keempat, pada saat ini pemberdayaan keterampilan yang dilakukan adalah kegiatan keterampilan membuat bahan dari kertas, kerajinan berbahan lidi, dan budi daya jamur. [ ]

\section{DAFTAR PUSTAKA}

Abbdullah, Irawan, tt. Metode penelitian Kualitatif, Makalah Workshop Metodologi Penelitian Berspektif Gender, Yogyakarta: PSW UGM.

Abdurrahman, Moeslim. 1995. Islam Transformatif, Jakarta:

Pustaka Firdaus.

Burhan Bungin, Metodolgi Penelitian Kualitatif, Aktualisasi Metodologis ke Arah Ragam

Varian Kontemporer, , 2001, Jakarta, Raajawali Pers

Budi Yana Saefullah, dkk., Pengorganisasian Rakyat, 2003Jakarta: INCIS

Chamsyah, Bachtiar, 2003, Dimensi Religi dalam Kesejabteraan Sosial. Jakarta: Depsos RI.

David C. Korten, Development as Human Enterprise, Community Management; Asian Experience and Perspectives, 1987, Conecticut: Kumarian Press

Departemen Agama RI. 1990. Al-Qur'an dan Terjemahnya, Jakarta: Lembaga Penerjemah Al-Qur'an.

Fadjar, Malik Madrasah dan Tantangan Modernitas, 1998, Bandung: Mizan

George Ritzer \& Douglas J. Googman, Teori Sosiologi Modern, 2008, Jakarta,

Kecana

http://id.wikipedia.org/wiki/Perubahan_sosial_budaya"

Harun Asrohah, Sejarah Pendidikan Islam, 2001 Jakarta: Logos

http://id.wikipedia.org/wiki/Perubahan_sosial_budaya

http://kabar24.bisnis.com/read/20150623/255/446327/

unicef-25-juta-anak-indonesia-putus-sekolah

http:// news.okezone.com/read /2015/08/17/65/119

74-07/70-tahun-ri-merdeka-anak-putus-sekolah-

masih-tinggi

Kamus Besar Bahasa Indonesia, http:/ / pusatbahasa. diknas.

go.id/kbbil index. Php

Mas'udi, Masdar F. 1991. Agama Keadilan: Risalab Zakat (Pajak) dalam Islam, Jakarta: Pustaka Firdaus. 
Nashir, Haedar, Agama dan Krisis Kemanusiaan Modern, 1999, Yogyakarta: Pustaka Pelajar

Nur Khoiron. M, et.al, Pendidikan Politik bagi Warga Negara, 2000, Yogyakarta: LKiS

Purwanto, Ngalim. M, Ilmu Pendidikan Teorotis dan Praktis,

Bandung: Remaja Rosda

Priyono dan Pranaka dalam Bagong Suyanto, 2005, "Pemberdayaan Komunitas

Marginal di Perkotaan",Dakwah Pemberdayaan Masyarakat: Paradigma Aksi Metodologi, Yogyakarta: Pustaka Pesantren,

Rukmana, Nana, Masjid \& Dakwah, 2002, Jakarta: al-Mawardi Prima

Sternbrink, Karl, Pesantren, Madrasah dan Sekolah, 1986Jakarta: LP3ES

Wilbert E. Maore, Order and Change, Essay in Comparative Sosiology, 1967, New York, John Wiley \&Sons

Undang-Dasar Republik Indonesia Tahun 1945, 2009 Surabaya: Indah

Undang-undang Republik Inonesia nomor 20 Tahun 2003 tentang Sistem Pendidikan Nasional, 2009 Yogyakarta: Pustaka Pelajar.

Walcott, Harry F, 1994, Transforming Qualitative Data, description, analysis and interpretation. California: Sage Publication.

Waidl, Abdul (ed.), Menuju Masyarakat Berdaya, 2008 Jombang: Lakpesdam NU Jombang

Wicaksono, A. Wazir \& Taryono D., Catatan Pertama, Pengalaman Belajar Praktek Pengorganisasian Masyaraat di Simpul Belajar, 2001,Bogor: Yayasan Puter. 
